\title{
INFORMAL SETTLEMENTS AND SQUATTING IN ROMANIA: SOCIO-SPATIAL PATTERNS AND TYPOLOGIES
}

\author{
Bogdan Suditu ${ }^{\mathrm{a} *}$, Daniel-Gabriel Vâlceanu ${ }^{\mathrm{b}}$ \\ ${ }^{a}$ Faculty of Geography, University of Bucharest, Romania \\ ${ }^{b}$ National Institute for Research and Development in Constructions, \\ Urbanism and Sustainable Spatial Development URBAN-INCERC, Bucharest, Romania
}

\begin{abstract}
The emergence of informal settlements in Romania is the result of a mix of factors, including some social and urban planning policies from the communist and post-communist period. Squatting was initially a secondary effect of the relocation process and demolition of housing in communist urban renewal projects, and also a voluntary social and housing policy for the poorest of the same period. Extension and multiple forms of informal settlements and squatting were performed in the post-communist era due to the inappropriate or absence of the legislative tools on urban planning, properties' restitution and management, weak control of the construction sector. The study analyzes the characteristics and spatial typologies of the informal settlements and squatters in relationship with the political and social framework of these types of housing development.
\end{abstract}

Key words: Informal settlements, Squatting, Forced sedentarization, Illegal building, Urban planning regulation.

Article Info: Manuscript Received: October 5, 2013; Revised: October 20, 2013; Accepted: November 11, 2013; Online: November $20,2013$.

\section{Context}

The analysis of human settlements and the identification of adapted legislative and operational solutions for the improvement of living conditions are presentday topics both for international scientific research and for international and national institutions having responsibilities in the field of housing and land management. In October 2013, during the $68^{\text {th }}$ Session of the General Assembly of the United Nations with the theme "Post-2015 Development Agenda: Setting the Stage", a report was presented on adequate housing as a component of the right to an adequate standard of living with a special focus on informal settlements. Solving the challenge posed by informal settlements is critical in order to reach the Millennium Development Goals, especially Target 11 on slums. The insufficient physical and social infrastructure and the lack of governmental involvement in the improvement of housing conditions for a series of informal settlements are factors leading to extreme poverty, high

\footnotetext{
* Corresponding author:

Address: University of Bucharest, Faculty of Geography, 1, Nicolae Bălcescu Avenue, o10041, Bucharest, Romania.

Telephone: +4021 3153074

Email: b_suditu@yahoo.fr
}

child mortality rates and precarious urban conditions (UN-HABITAT, 2003).

The topicality of informal settlements' issue is widely recognized in the main European and international strategic documents on housing such as: Habitat Agenda (1996), Declaration on Cities and Other Human Settlements in the New Millennium (2001), European Social Charter, revised (1996), the Vienna Declaration on National and Regional Policy Programmes regarding Informal Settlements in SouthEastern Europe (2004), Millennium Development Goals, Leipzig Charter on Sustainable European Cities (2007), Report on Housing and Regional Policy initiated by the Italian Member of the European Parliament Alfonso Andria (2007), Europe 2020 Strategy.

The Vienna Declaration identifies the issue as a priority, supporting the idea that housing policies must aim to regularize informal settlements and to improve the living conditions of informal settlements. According to the Declaration, sustainable urban management requires for the informal settlements to be integrated in the social, economical, legal and spatial network, at local level. The success of the legalizing efforts contributes to the long-term economic growth as well as to social equity, cohesion and stability (Vienna Declaration, 2004). At the Eu- 
ropean level, a pronounced dynamics regarding the forming and development of informal settlements can be noticed both in the developed countries from Western Europe and in less developed countries in Eastern and South-Eastern Europe, especially in former communist ones. In some cities in former communist countries, the forming and development of informal settlements represent a phenomenon associated with an urbanization wave that took place between 1960 and 1970, and the expansion of the phenomenon is closely connected with the massive flow of immigrants and refugees in the 9o's. The areas with informal settlements are the results of different factors: inappropriate territorial planning, inadequate legislation and unadapted to the territorial reality, housing policies lacking provisions for ensuring affordable housing as well as inefficient structures of public administration (Tsenkova, 2010).

In Romania, the phenomenon of informal settlements' occurrence and development hasn't been analyzed and quantified in thematic researches up to now. The issue of these settlements' insalubrity and marginalization from a social and spatial point of view can be found in numerous studies regarding the quality of life in disadvantaged communities, especially Roma communities (Nae, 2007; Mionel, 2013). The main researches and discussions on identifying, analysis and solving the technical and legal aspects related to this type of human settlements were addressed by the Working Group on Roma Housing within the Ministry of Development, Public Works and Housing (2007), which materialized in two thematic projects: „Methodology for the rehabilitation of housing in the areas affected by physical degradation and social exclusion" (2008) and "Analysis of informal settlements in Romania - assessing the current situation and the formulation of rules and tools of intervention" (2012). The present study provides a series of results from the above-mentioned studies where the authors were involved in, concerning the definition, characterization and the establishment of typologies of informal settlements and squatting in Romania (Photo 1).

\section{Multiple terminologies for a precarious social- geographical reality}

UNECE (2009) offers a concise definition that stands as the basis for the majority of specialized studies. According to this definition, informal settlements are defined as "illegal" residential formations lacking basic infrastructure, security of tenure, adequate housing, etc." In Vienna Declaration (2004), informal settlements are defined as:

"human settlements, which for a variety of reasons do not meet requirements for legal recognition (and have been constructed without respecting formal procedures of legal ownership, transfer of ownership, as well as construction and urban planning regulations), exist in their respective countries and hamper economic development. While there is significant regional diversity in terms of their manifestation, these settlements are mainly characterized by informal or insecure land tenure, inadequate access to basic services, both social and physical infrastructure and housing finance"

(Vienna Declaration, 2004).

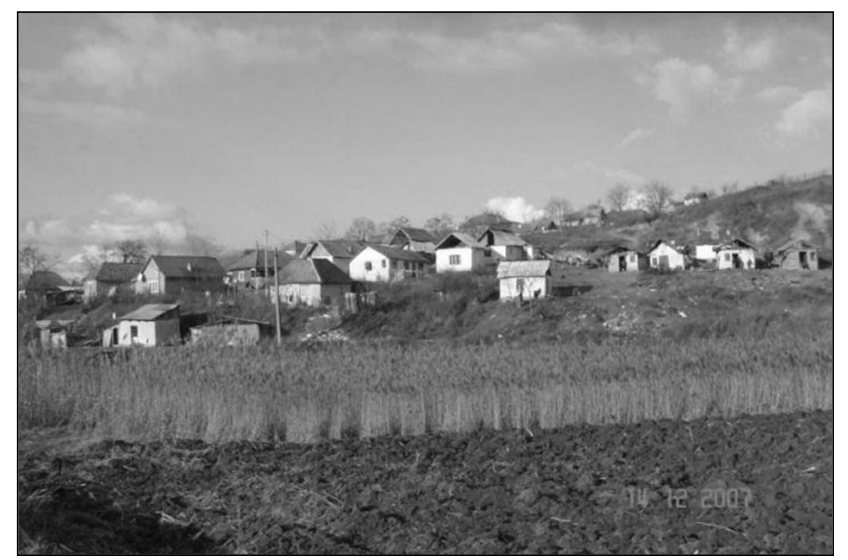

Photo 1. Roma informal settlements formed as a result of forced sedentarisation in the '5os on the outskirts of Unirea, Cluj county (Photo: B. Suditu, 2007)

According to the definition suggested by the Economic Commission for Europe in 2008, an informal settlement represents:

"any human settlement where housing has been constructed without the requisite legal title for ownership and/or use of the land for residential purposes. References to illegality refer mainly to conformity with planning, zoning and construction norms and, more importantly, to tenure situations, e.g., squatting on public or private land. Residents of informal settlements often lack legal rights to the land and the house and are vulnerable to eviction. This vulnerability is sometimes amplified by a general inadequacy of housing, access to services, transportation, education and healthcare that result from the physical and legal marginalization of these settlements from their broader urban community" (Economic Commission for Europe, 2008).

A very clear distinction has to be made between informal settlements and squatting, two concepts with different significance. The squatting (informal or abusive use of housing) consists of occupying an abandoned or unoccupied area of land and/or a building- usually residential. From a territorial profile point of view, the manifestation form of this housing type is translated into the illegal occupancy of a house having an uncertain status of tenure and being usually legally built (squatting phenomenon), while the informal settlements can be defined in the Romanian territorial context as groups of houses usually developed at the outskirts of urban or rural localities, where the lands are legally or illegally occupied and 
the buildings are unauthorized or respect the building permits only partially, and whose main characteristics are lack of access to the basic urban infrastructure, inappropriate housing conditions etc. jeopardizing the safety and the health of the occupying population.

Informal settlement is a term used for a broad range of underdeveloped and illegal settlements, formed on free lands occupied by low income families, without having the permission from their rightful owners and/or independently from the central authorities responsible with the institutional or external control on the local building and planning mode (Turner, 1969, p. 508). These are houses having characteristic elements such as: uncertain tenure status, illegal occupying, low safeness and usually precarious housing conditions. Apart from these, one can add precarious transportation infrastructure, lack of access to the public infrastructure of running water, sewerage, gas and even electricity, elements contributing to the character of insalubrity and public danger to the population's health. The term can be also defined as a group of houses usually built on illegal lands, without building permits and following their own rules, often inhabited by individual or collective groups. They are housing types marked by illegal status: lack of ownership to the land, lack of safeness, lack of access to urban utilities etc.

The term "informal settlement" became widely known after the Conference on Human Settlements in Vancouver (1976). Payne (1977) considers that the forming and development of illegal and inadequate settlements is the result of the global perspective of urban growth in Third World states and its inevitable character. A "squatter" is a person who settles on an urban or rural land without having any legal right (Abrams, 1971). The following terms are also used: "squattage" and "squatment" meaning occupying a land by a squatter, "squatterism" meaning getting a piece of land by "squatting" and "squatterdom" or the collective squatters' organism. The term squatting defines a breach of ownership rights where two ownership elements are involved: land and building.

The term slum is used in reference to the illegal settlements. Encyclopedia Britannica defines the term slum as:

\footnotetext{
“... a residential areas that are physically and socially deteriorated and in which satisfactory family life is impossible. Bad housing is a major index of slum conditions. By bad housing is meant dwellings that have inadequate light, air, toilet and bathing facilities; that are in bad repair, dump and improperly heated; that do not afford opportunity for family privacy; that are subject to fire hazard and that overcrowd the land, leaving no space for recreational use".
}

The slum definition is often found in international studies in this field. According to Bergel (1955), the slum can be characterized as an urban area with housing conditions under the minimal legislative standards. The term "housing conditions" goes beyond the physical aspect of a building, referring to the living conditions. The term of "substandard" must be understood considering the fact that the slum is a complex product of many factors such as social phenomena taking place in a city's territorial profile. Clinard (1966) defines the slum as an overcrowded area of buildings, overcrowded houses or both. Ford (1936) offers a definition of term as a residential area where the house is deteriorated, substandard or unhealthy and represents a threat to the occupant's health, safeness, morality and wellbeing. Abrams (1971) defines the slum as a building or area which is deteriorated, dangerous from the perspective of the structural strength, unhealthy or lacking comfort standards; it is also characterized by insalubrity, overcrowding or unhealthy conditions, regardless of the physical situation of the building or area.

Initially, these two terms - squatter settlement and slum - were synonymous, but the researchers in the field use them separately. Nevertheless, there is a difference between the terms of squatter settlement and slum: on one hand - the term slum may be defined as permanent, legally built buildings where living conditions are precarious due to the building's age, its advanced physical and structural degradation, insufficient living space and overcrowding; in time, the living conditions in slums tend to deteriorate. The housing characterizing illegal settlements (informal settlements) is substandard, its main elements being lack of tenure safety and access to basic urban infrastructure. If the perceived level of tenure security increases and other living conditions improve as well, living in such settlements also tends to improve in time (Photos 2).

A relatively broad range of terms for defining and characterizing the informal settlement concept has been used in studies dedicated to this phenomenon: Squatter settlements (Willis, 2009), Shanty town (Auyero, 200o; D'Cruz et al., 2009), Informal settlements (Vienna Declaration, 2004; UNECE, 2009; Tsenkova, 2010), Autonomous settlements (Turner, 1969), Extra-legal settlements (Rodwin and Sanyal, 1987), Popular settlements (Aina, 1990), Self-help settlements (Gilbert, 1999; Gough and Kellett, 2001; La Ferrara, 2002; Zhang et al., 2003), Spontaneous settlements (Dwyer, 1979), Shack settlements (Mason and Fraser, 1998; Selwood and Jones, 2010), Low-income settlements (Yeh, 1987; Matovu, 200o; Aluko and Amidu, 2006), Semipermanent settlements (Hurskainen, 2004; Ahmad et al., 2012), Unauthorized settlements (UN-HABITAT, 1996), Unplanned settlements (Ali and Sulaiman, 2006), Uncontrolled settlements (Ahmad and Choi, 2011), Irregular settlements (Moser and 

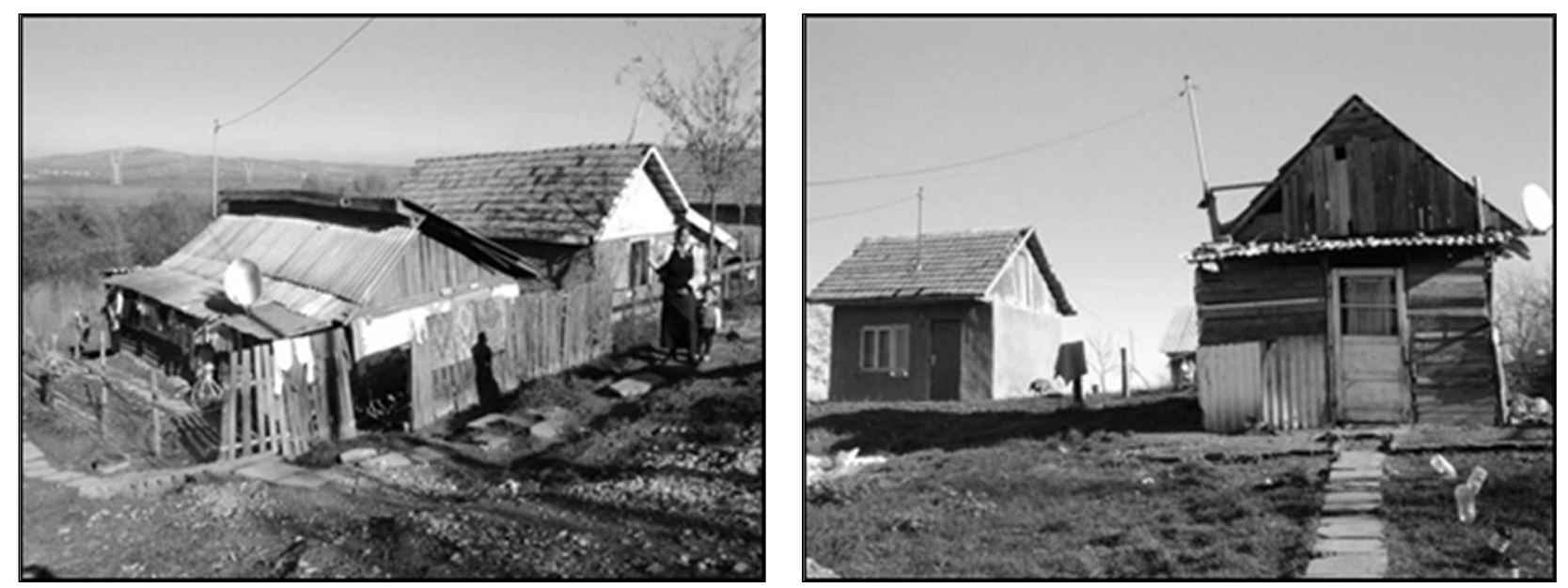

Photos 2. Informal settlements, occurring spontaneously and developed in an uncontrolled manner — Luduș, Mureș County (Photo: D.G. Vâlceanu, 2013)

Peake, 1987, p. 37; UN-HABITAT, 1996; Ward, 2001), Marginal settlements (Solaun et al., 1974; Peattie and Aldrete-Hass, 1981; Plöger, 2012).

We also notice that these types of informal settlements are habitually differently named in different countries in the world: in Latin America - barrios piratas or clendestinas (Colombia), colonias letarias or paracaidistas (Mexico), ranchos (Venezuela), callampas or campamentos (Chile), villas miserias (Argentina), barriadas (Peru, Panama and Colombia), favelas (Brazil); in USA -ghetto; in Asia - bustees or jhuggis (India), kampung (Indonesia), barong-barong (Philippines), setinggan (Malaysia), chumchaon bukruk (Thailand), nhaa tam bo (Vietnam), sukumbashi (Bangladesh), muhogu chongchakji (Republic of Korea), palpath (Sri Lanka), kachi abadi (Pakistan), kevettits (Burma); in Africa -gourbivilles (Tunisia), bidonvilles (Morocco); in Europe -bidonville (France), borgate (Italy), chabolas or guetos (Spain) gecekondu (Turkey), bairros de lata or favelas (Portugal), domiki (Armenia).

In Romania, we consider the followings sociogeographical realities as informal settlements:

a. groups of housing units and shelters made of reused or poor quality materials, formed from family nuclei of Roma population voluntarily or forcedly settled down at the beginning of the communist period, placed on lands for which the occupants have no real tenure rights;

b. housing units built without building permits and in violation of land use plans and building standards, even if their owners have real rights over the lands they are building on.

As regards terminology, we should mention that neither in the specialized literature nor in daily practice there is a specific term which should define precisely the informal settlements. Currently, for the definition of small, shabby houses, improvised or made from recycled materials or from earth and wood, are used the terms of cocioabă (sg.) / cocioabe (pl.), magherniță (sg.)/ maghernițe (pl.) and also șandrama (sg.)/ șandramale (pl.). In the case of the provisional wooden constructions, as it is the case of the groupings of shelters made for workers from the construction sites or industry, the term is that of baracă (sg.) / barăci (pl.). (DEX - Explanatory Dictionary of the Romanian Language, 2005).

We signal that the use of the word mahala which describes informal settlements is inappropriate (Mionel, 2013). The term mahala (Turkish> mahalle "neighborhood") is an archaism that describes neighborhoods located at the periphery of cities, as well as their population, without explicitly translate their informal nature. Currently the reference to mahala has no longer a spatial meaning, but only a social pejorative significance, indicating deficiencies of education and inadequate social behaviour (Photos 3 ).

\section{Determinant factors for the formation and development of informal settlements}

\section{Historical factors}

In Romania, the main factor responsible for the formation and development of present-day informal settlements' nuclei is related to the settling down of Roma population during the communist period. The location of the first communities was most of the times aleatory, except for those situations where the new created communities were settled down near already existing Roma communities. Ever since 1948, the communist régime initiated a vast operation for identifying Roma camps and for registering them at the population records offices, adopting a sedentary policy of nomadic Roma population. For many of these so formed communities, the state intervention was well-timed as their members were supported with loans and subsidies for housing construction, 

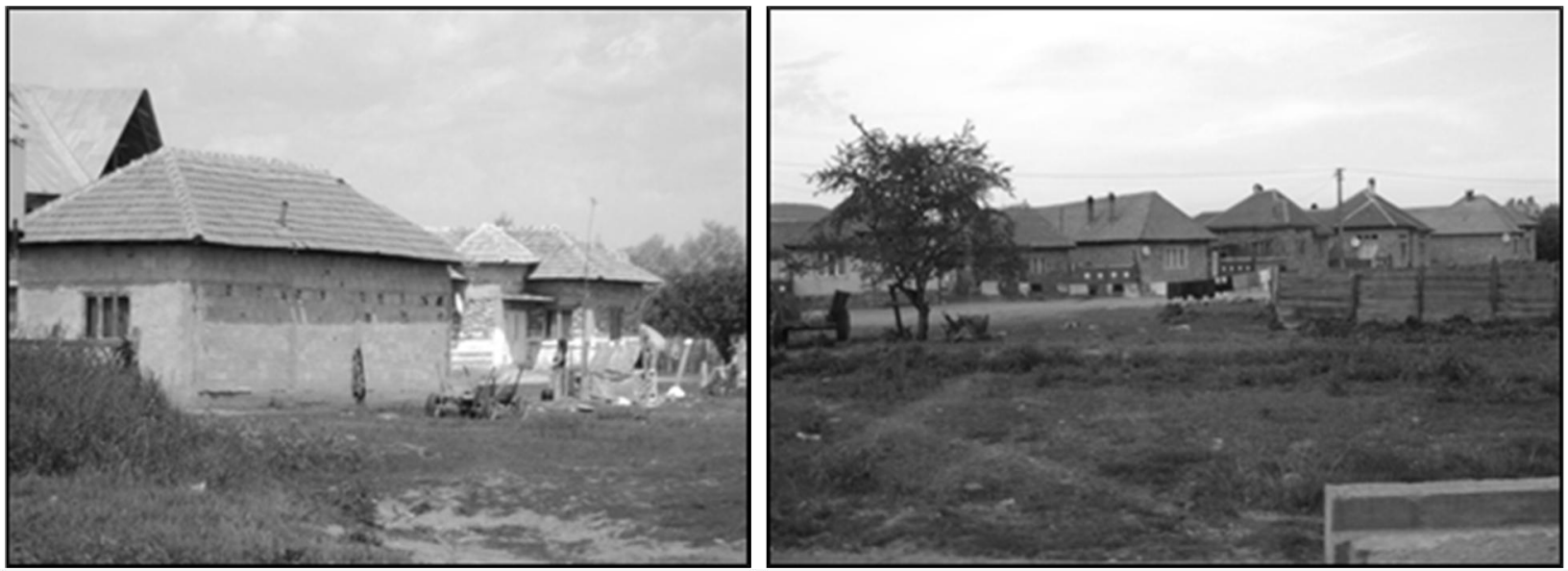

Photos 3. Roma housing groups, occurring spontaneously and developed in an uncontrolled manner - Piatra Olt, Olt County and Sâmbăta de Jos,Brașov County (Photo: D.G. Vâlceanu, 2013, B. Suditu, 2013)

which led to the natural development of the community and their integration (National Culture Center of Roma, 2010).

The socialist régime intended also the "Romanization" of Roma population's habitat through their settling down and through measures for the elimination of nomadism.

Together with the policy of villages' forced systematization, the Roma people were moved into buildings situated at the outskirts of villages or cities or in the houses of Saxon, after the emigration of the Saxons, as it happened in Transylvania. Even though the living conditions were much better, they adapted difficultly to their new style of life (Presidential Commission for the Study of the Communist Dictatorship in Romania, 2010). Starting with 1977 a series of special measures in favor of nomadic Roma population's settling down was adopted nationally; in that particular year the Central Committee of the Romanian Communist party adopted a program for their social integration (NCCR, 2010). As part of the territorial systematization process, the communist régime policy was also an attempt to forcedly put the nomadic Roma people in the cities' poor ghettos or in the semi-urban-type settlements from agricultural areas (Fraser, 2008) (Photo 4).

\section{Social-economical factors}

The evolution of social and economical conditions in the context of 1950-1975 crisis in Eastern Europe had a series of repercussions on nomadic Roma population, translated into the impossibility for them to settle down or/and to live a semi-nomadic life, as well as their exclusion from the new economic strategies (NCCR, 2010). In the study conducted by UNECE (2009), these factors are linked to a series of major interdependent changes such as:

a. On one hand, rapid urbanization within the socialist policy for territory systematization and forced residential mobility enforced by the new requirements of industrialization with respect to labor force;

b. On the other hand, the post-socialist restructuring of the national economy led to more poverty and social exclusion, especially to the limitation of the housing access right.

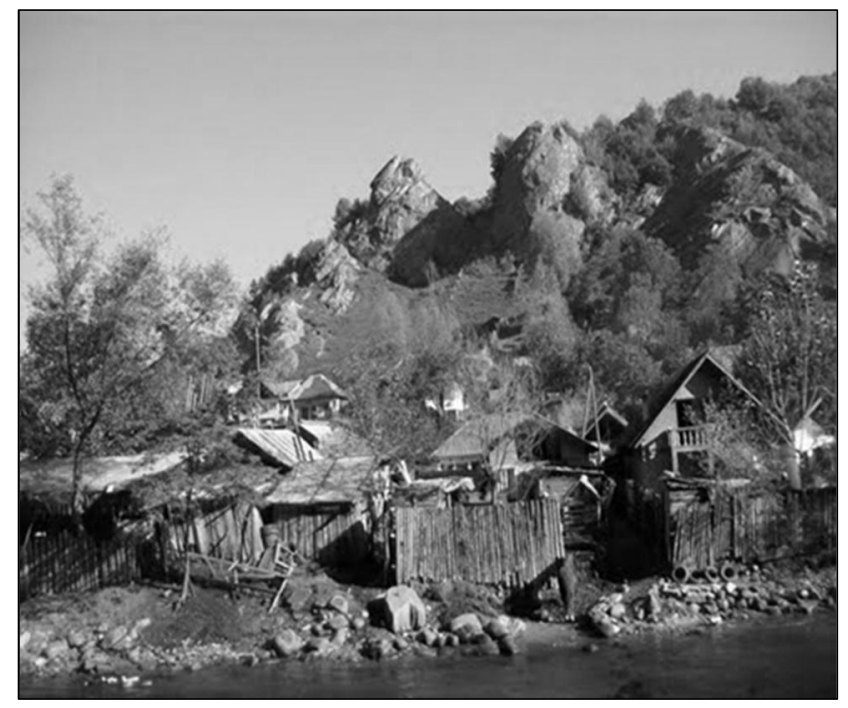

Photo 4. Informal settlements emerged in the 30 result of colonization and further developed over the archaeological site - Cetățeni, Argeș County (Photo: D.G. Vâlceanu, 2013)

A series of adjacent factors with impact on the formation and development of informal settlements after 1990 also contributes to these two major changes:

c. inappropriate tools for public land administration;

d. an inappropriate territorial planning system, which led to the difficult integration of these segregated territories into the built-up areas of the localities, especially during the transition period;

e. lack of affordable houses and available lands for disadvantaged categories of population. 


\section{Political and legislative factors}

Following the abolition of the law no 58/1974 on territorial and urban systematization after the Romanian revolution from December 1989, for more than a decade up to 2001 the localities developed in the absence of a legal framework for land management and urban planning. The switch from territorial systematization plans specific for the socialist period to the general urban plans during the post-socialist period generated a series of difficulties with respect to the integration of certain territories with informal settlements into the built-up area, which allowed them to further develop without respecting the regulation framework in place, but also without any possibility to legalize them. The violation of urban regulations and the lack of control of building standards are responsible for the significant number of illegally built houses or houses that don't fully respect the building permit. The spatial manifestation forms of the informality phenomenon were initially assigned to the inexistence of a land planning and management system, to the absence of flexible and integrative operational solutions from the urban plans in the context of the new dynamics of urban and rural localities' development. In many cases, generations of urban documentations approved in the last two decades didn't suggested any urban planning solutions for the areas with informal settlements, except for few cases, leaving them outside the built-up areas. In fact, following the principle that what is not legal should not exist in reality or in documents as well, some groups of such houses - part of them located in areas of biological or natural hazards - are not even mentioned in urban planning documentations.

Perhaps one of the most important political factors hampering the identification of technical and legal solutions for informal settlements is related to the absence of this topic from the public and political agenda. In this respect, the legislative solutions for solving the informality have been designed without a general approach of the informality (with or without building permits, ownership right on the land or not, belonging to the state, local authority or a private owner), without an assessment and an analysis of the overview territorial reality and without committing to the subsequent public actions deriving from these settlements/houses legalization, especially when the occupants are marginalized ethnical or economical groups (Photos 5).

\section{Social-spatial and legal characteristics of informal settlements}

Most of informal settlements' definitions stress the illegal character of housing construction as well as the violation of rules established in urban planning documentations. Compared to the European informal settlements' characteristics, the Romanian ones include a series of common characteristics: uncertain tenure status (houses usually built on lands with a different status than that of the occupants'); total or partial violation of building permits; lack of basic services (lack of access to the main urban infrastructure); substandard houses or illegal or inappropriate building structures; settlements' fragmentation; poor quality construction materials (timber framework, clay bricks, materials reused from demolitions etc.); overcrowding; occupants affected by poverty and social exclusion; precarious living conditions, dangerous to the resident population's health (UN-HABITAT, 2003; Payne and Majale, 2004; Tsenkova, 2010).

In regard to these general features, the informal settlements in Romania have the following characteristics:

a. Physical characteristics. Due to their illegal status, they don't generally benefit from an appropriate urban planning; apart from this, there is also the lack of access to the urban infrastructure (water, sewerage, roads, electricity, gas), social infrastructure (schools, medical centers, cultural centers, commer-
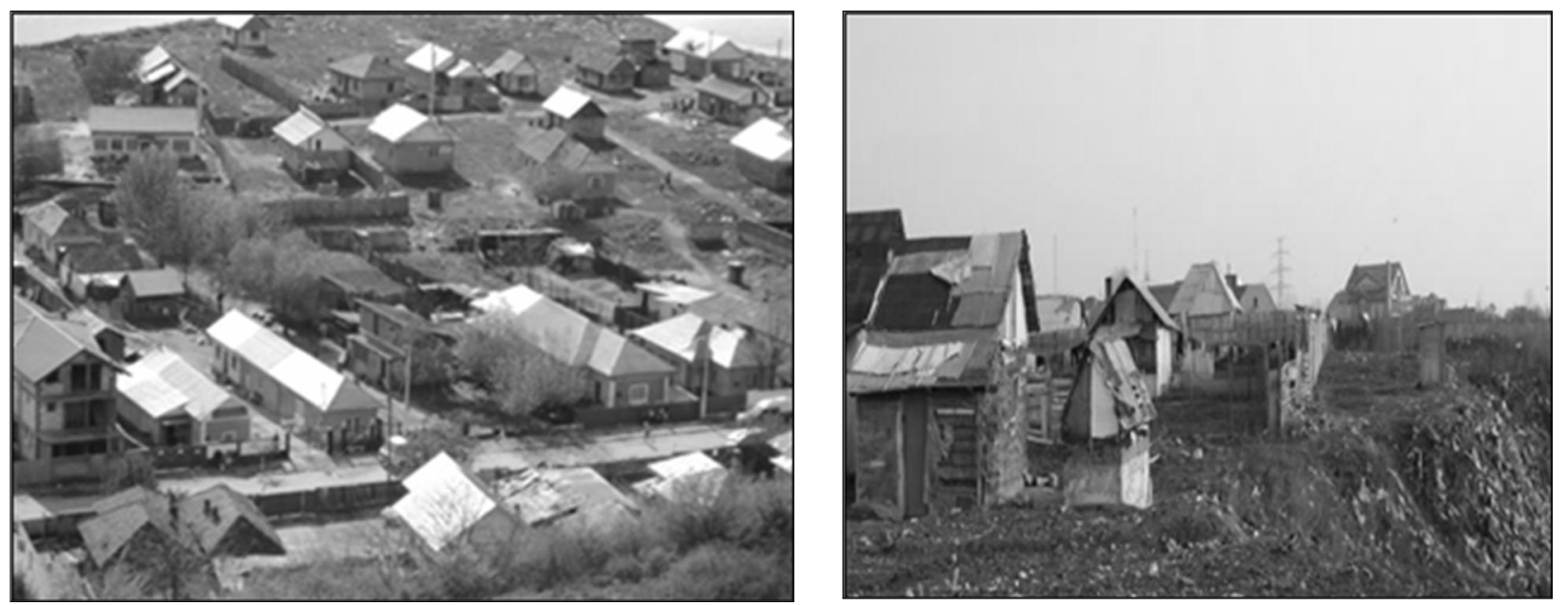

Photos 5. Illegal houses built outside the localities built-up area — Slatina, Olt County (Photo: D.G. Vâlceanu, 2013) 
cial spaces etc.); the public authorities are not able to ensure the access to the urban infrastructure; the expenses for making it - in case it exists - are born by those who built the houses;

b. Social characteristics. There are two different situations depending on the ownership of the informal settlements' lands. When there is no real right on the lands the houses are built on, the occupants belong to the category of vulnerable social or ethnical groups. The social mix generated by the socialist process of forced industrialization led to their postsocialist "enclavization".

This involuntary process generated in the context of great social-economical transformations and the permissive legal framework, together with the restitution of gold reflects upon the present heterogeneous and unaesthetic urban landscape. The positioning of these types of settlements in the localities' territorial profile is not based on a controlled process, dictated by the urban development policies, but it is in fact a spontaneous process and a product of the socialeconomical and political transition context from a planned economy to the free market economy. The vulnerable groups don't include only Roma residents, which are the majority residents of these settlements, but also autochthonous population - jobless youngsters, unemployed people, people with disabilities, older people. When those who built their houses have an ownership right on the lands, but they made them without having a building permit, there is a great diversity socially, the occupants belonging to all social, professional and income categories.

c. Legal characteristics. The informal character of these settlements is closely connected to the legal status of the buildings and the lands they are built upon. Thus, in Romania we can consider informal settlements on one hand - the groups of houses made without a building permit on lands for which the builders have no ownership right and on the other hand - the residential developments where those who build their houses rightfully own the lands, but they violate the legal regulations on urban planning (buildings outside the built-up area or buildings that violate the provisions of in place urban plans) and constructions' authorization. For most of informal settlements, the legal status of the land is uncertain or illegal and the legal status of the building depends on that of the land. During the post-communist period, the development of new residential areas through urban sprawl and the strong reduction of authority for those public institutions in charge with the control of building standards generated an unprecedented growth of illegally built houses inside or outside the localities built-up area (Suditu B., 2012).

\section{Typologies of informal settlements}

Given the morphological and spatial characteristics as well as their location in relation to the perimeters of towns that could be built on, the following types of informal housing were identified:

1. Grouping of newly built homes, built without permit, located inside or outside the city, due to the perimeters developed as a consequence of postcommunist urban sprawl. Informal settlements of this type are constituted mostly of good quality housing made of resistant materials. Also, their location within or outside city limits, in the context of the intense dynamics of this perimeter, is temporary and relatively random. Thus, many groups of informal housing or settlements were initially built entirely outside city limits, and later on, at the moment of the update/change of the planning documents, the lands they were located on were later introduced in town. The process is however not generalized, and nowadays there are informal settlements or groups of homes built outside the limits of the town, so, without a building permit.

2. Improvised dwellings, built without a permit, located in town, in areas that according to the general planning documents (PUG - General Urban Plan) have functions that exclude housing. These informal settlements regroup improvised and unsanitary buildings as well as ethnic categories and economically marginal population and are located in areas that have no functions of housing: natural risk areas (landslides, floods, earthquakes, etc.), industrial areas, the waste dumps, the protection and safety of utilities area etc. This also includes groups of Roma houses illegally built in protected natural areas (nature reserves, Natura 2000), protected built areas (archaeological sites), or in protection zones (public utility networks, industrial objectives, etc.).

3. Informal settlements comprising groupings of buildings having the function of temporary shelter, which becomes later on permanent. This category includes groups of barăci from the workers' colonies built to accommodate workers involved in the development of hydraulic works, various mining (coal, metal etc.) or employees of large industrial plants (steel etc.).

4. Housing of Roma communities, which resulted from forced sedentarization, spontaneous development or were relocated as a result of expulsion, located within or outside city limits, built without planning permission. The main informal settlements of this type are: groups of Roma housing built as a result of forced sedentarisation in '50-60 and subsequently extended, situated on the outskirts of towns or isolated from them, in which the construction of good or poor quality are realized without a building permit, Roma housing groups, occurring spontaneously and developed in an uncontrolled manner on different lands 

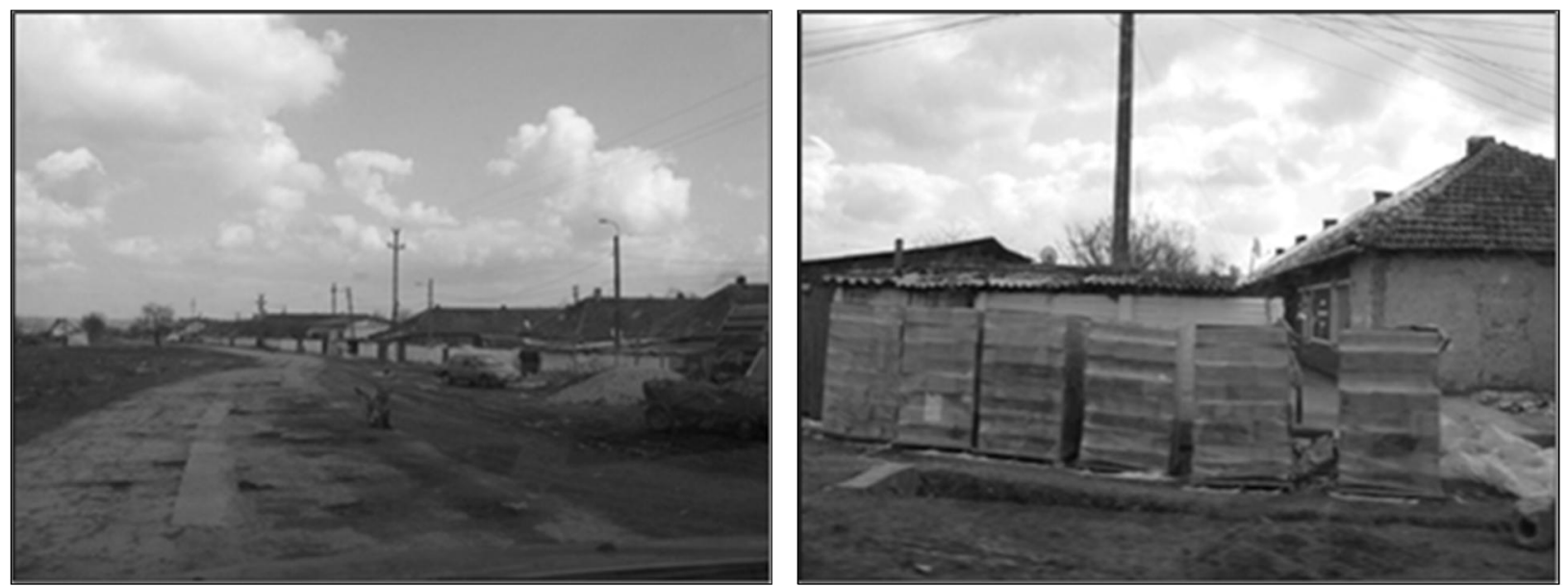

Photos 6. Colony of barracks developed near to Recaş tile factory, Timis County (Photo: B. Suditu, 2013)

occupied without respecting the legal framework for territorial planning and construction authorization (Photos 6).

\section{Squatting or on illegal and abusive occupation of the existing buildings}

Unlike informal settlements, the illegal housing refers to the occupancy without any legal right of some constructions that already exist by individuals or families belonging to ethnically or socially marginalized groups.

The most numerous situations identified in Romania are the following:

a. Housing and other buildings evacuated by their owners / tenants for demolitions purposes in the framework of projects of urban renewal of the communist period, occupied by ethnic and economic marginalized people;

b. Nationalized buildings, owned by the state and the public authorities, abandoned by these ones and / or abusively occupied by different categories of ethnic and economic marginalized people;

c. Saxon Houses from Transylvania occupied by Roma people or assigned to these ones during the communist period, after the emigration of the Saxons (Photo 7)

The first cases of squatting are connected to the eviction-relocation process within big city centers' renovation projects in Romania at the end of the '8os. In this process, together with the eviction of owners or tenants from the houses situated near the demolition sites, groups of ethnically and/or socially marginalized people used to occupy the evicted houses for a few days, using them as a temporary shelter until the bulldozers appeared. This is why numerous houses initially occupied only for few days during that period, are still occupied as a result of the communism fall and demolitions' arrest, the abusive occupants remaining inside even now, 23 years afterwards.

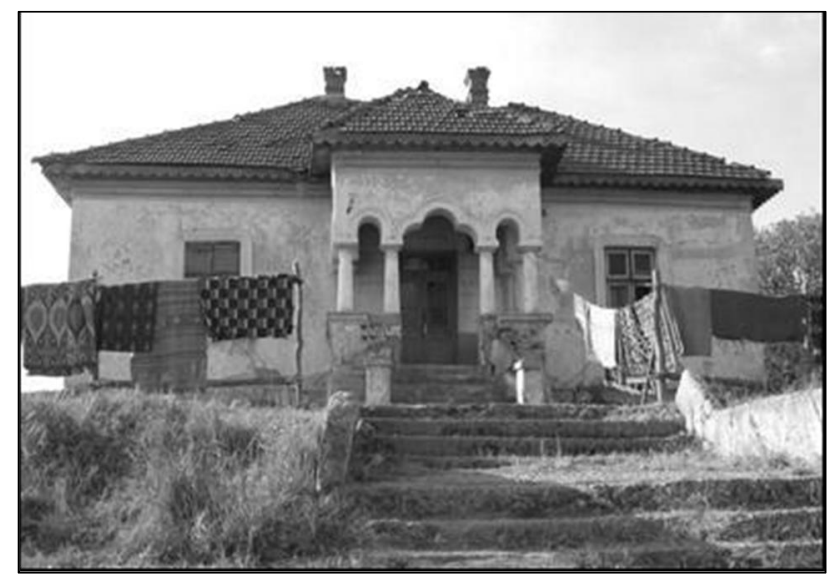

Photo 7. Mansion at Erghevita, Mehedinti County, nationalized in 1948, used as headquarters of the Agricultural Cooperative (C.A.P.) by the 90 and later dropped (Photo: B. Suditu, 2011)

Another situation of informal housing is linked to the abandonment or bad management after 1990 of some unused nationalized buildings, degraded and / or were not returned to their jure owners. These buildings, housing different public institutions or used as social houses, haven't been well managed by the public authorities, being abusively occupied by Roma people or different economically marginalized people. These buildings were used as illegal houses until a legal resolution was in place if the owner wished for regaining the ownership (Photos 8).

The uncertain legal status of land and some buildings' ownership after 1990 generated by legal gaps in Law no. 112 /1995 on the settlement of the legal condition of some buildings designed fordwelling purposes, passed into State property, Law no. 231 / 1998 on public property and its legal status or Law no. 18/1991 on the land fund led to an accentuated dynamics of the informality phenomenon, both at the settlements' level and the housing one. Therefore the groups of socially vulnerable persons occupy illegally the usually uninhabited buildings, decisively contributing to the aggravation of those respective buildings' total degrada- 

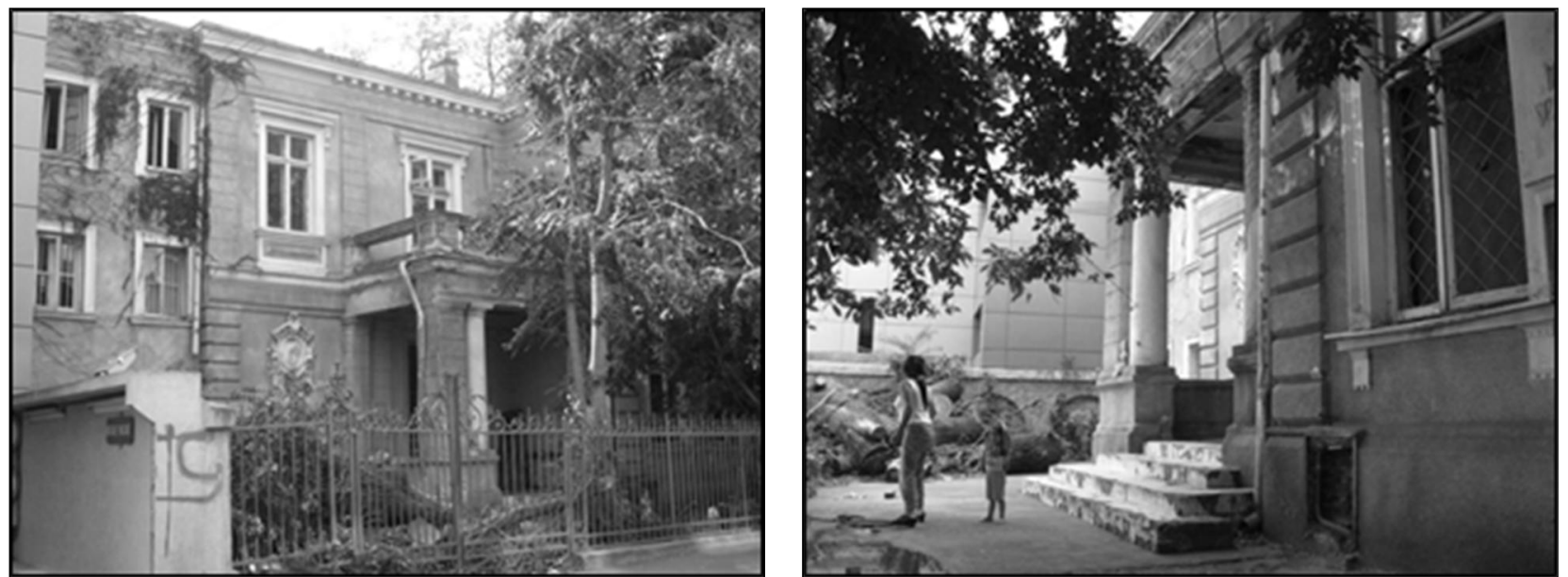

Photos 8. The home of Spiru Haret, Minister and promoter of the Romanian education reform at the end of XIX century, was donated by that State to become the Museum of teaching. In the communist period is the headquarters of the Handicraft Cooperative Association, the seat of a football club, and after 1990 was abandoned, becoming temporary shelter for some poor Roma families. Gh. Manu street, Bucharest (Photo: B. Suditu, 2011)

tion or destruction. A particular situation is represented by those buildings situated in central areas of big cities, some of them heritage buildings, having an uncertain legal status or usage.

Sometimes, especially in the case of heritage buildings that have no real estate value in themselves but by the value of the land and by real estate speculation, by the urban derogation of a future construction, the buildings are illegally occupied by vulnerable groups with the owner's agreement, in order to contribute to the physical and structural degradation, which goes sometimes to their burning downs, easing the way to get a demolition permit in order to release the land.

The latter abusive living situation, established with the support or tacit consent of the communist state, concerns the occupying of the houses of Saxons from Transylvania after their emigration in Germany. Since obtaining a passport depended, among other things by the sale or disposal to the state of the houses of Saxons, In Saxon villages, the dwellings of Saxons were used as housing for the Roma that were to be sedentarized. In other cases, after the Saxons have left, the houses have been occupied without the involvement and complicity of the communist state (Photo 9).

\section{Conclusions}

The analysis of social and spatial characteristics of informal settlements and illegal housing confirms the diversity of housing situations in Romania. Improving the living conditions of individuals and communities targets legal, social and urban issues. Solving the informal situations implies territorial recognition and quantification of phenomena, and building legal and spatial planning tools adapted accordingly. But the most important aspect in solving the informal settlements situations in the European states is their recognition as a major problem for societies and the inclusion of appropriate public policies on the political agenda.

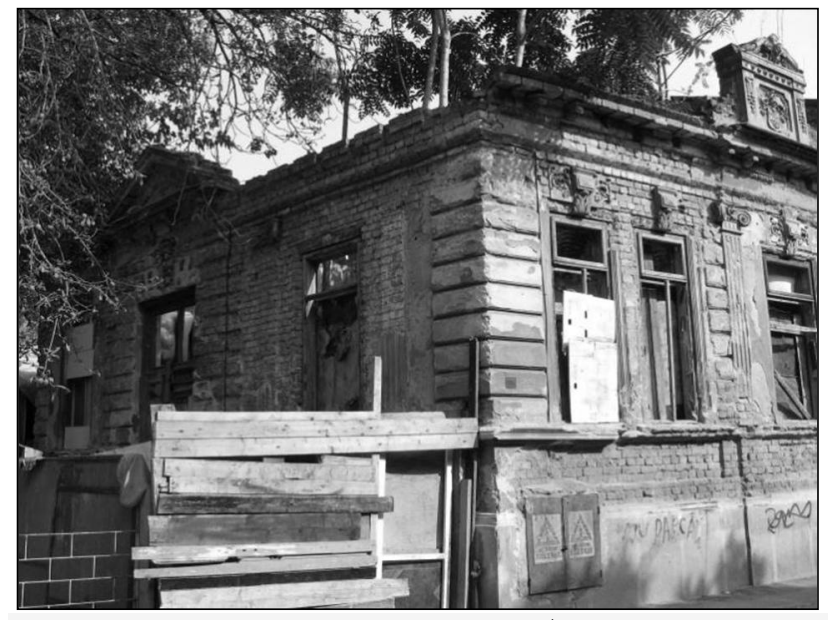

Photo 9. Bourgeois house in Bucharest (Uranus - Antim area), nationalized in the $5 \mathrm{o}^{\text {th }}$, used as social housing and abandoned in the 8 os in the surrounding area was demolished to achieve the Civic Center and the People's House, currently used as shelter for low-income people. (Photo: B. Suditu, 2012)

\section{Acknowledgment}

We dedicate this paper to the memory of Nicolae Gheorghe (1946-2013), distinguished Romanian intellectual of Roma origin, rational and professional militant for the study and official recognition of the realities of informal settlements, as well as for finding tailored solutions in view of improving the quality of life of their inhabitants. 


\section{References}

Abrams, C 1964, Man's Struggle for Shelter in an Urbanizing World, The MIT Press, Cambridge.

Ahmad, S \& Choi, MJ 2011, 'Research Note - The context of Uncontrolled Urban Settlements in Delhi', Asien, vol. 118, pp. 75-90.

Ahmad, S, Sridharan, N \& Kono, N 2012,'Housing Supply in Unauthorized Settlements in Delhi: Process and Outcomes', $48^{\text {th }}$ ISOCARP Congress, Delhi.

Aina, TA 1990,'Petty landlords and poor tenants in a low income settlement in metropolitan Lagos, Nigeria', in $\mathrm{P}$ Amis \& P Lloyd (eds), Housing Africa's Urban Poor, pp. 87 - 102, Manchester University Press, Manchester.

Ali, MH \& Sulaiman, MS 2006, 'The causes and Consequences of the Informal Settlements in Zanzibar', XXIII FIG Congress, 8-13 October 2006, Munich.

Aluko, BT \& Amidu, AR 2006, 'Urban Low Income Settlements, Land Deregulation and Sustainable Development in Nigeria', $5^{\text {th }}$ FIG Regional Conference of Promoting Land Administration and Good Governance, March 8-11, 2006, Accra.

Auyero, J 2000, 'The Hyper-Shantytown. Neo-Liberal Violence(s) in the Argentine Slum', Ethnography, vol. 1, no. 1, pp. 93-116.

Centrul Naţional de Cultură a Romilor 2010, E Marushiakova \& V Popov (eds.), Istoria romilor. Comunismul,

http://romanikultura.ro/docs/Istorie/6.1_Comunismul_R O.pdf.

Comisia Prezidenţială pentru analiza dictaturii comuniste din România 2010, Raport final, București, http://www.presidecy.ro/static/ordine/RAPORT_FINAL_ CPADCR.pdf

D'Cruz, C, McGranahan, G \& Sumithre, U 2009,'The efforts of a federation of slum and shanty dwellers to secure land and improve housing in Moratuwa: from saving groups to citywide strategies', Environment \& Urbanization, vol. 21, no. 2, pp. 367-388.

Dwyer, DJ 1979, People and housing in Third World cities: Perspectives on the problem of spontaneous settlements, Longman, London.

Economic Commission for Europe 2008, In search for Sustainable Solutions for Informal Settlements in the ECE Region: Challenges and Policy Responses', Unedited Draft, sixty-ninth session, Geneva,

http://www.unece.org/fileadmin/DAM/hlm/sessions/doc s2008/informal.notice.1.pdf

Elder, G 2006,'Squatter settlement', in B Warf (ed), Encyclopedia of human geography, pp. 459-461, CA: Sage Publications, Thousand Oaks.

Filcák, R 2012,'Environmental Justice and the Roma Settlements of Eastern Slovakia: Entitlements, Land and the Environmental Risks', false Sociologicky Casopis, vol. 48, no. 3, pp. 737-762.

Ford, J 1936, Slums and housing, with special reference to New York City: history, conditions, policy, Volume One, 1st edition, Harvard University Press.

Fowler, HW \& Fowler, FG 2008, Concise Oxford English Dictionary: Eleventh Edition, Revised 2008, Publisher: OUP Oxford, 1728 pp.

Fraser, A 2008, Ţiganii, Ed. Humanitas, București, pp. 298299.
Garstka, GJ, 2010,'Post-conflict urban planning: The regularization process of an informal neighborhood in Kosova/o', Habitat International, vol. 34, issue 1, pp. 86 - 95, ISSN 0197-3975.

Gilbert, A 1999, 'A home is for ever? Residential mobility and homeownership in self-help settlements', Environment and Planning A, vol. 31, no. 6, pp. 1073-1091.

Gough, VK \& Kellett, P 2001, 'Housing Consolidation and Home-based Income Generation: Evidence from Self-help Settlements in Two Colombian Cities', Cities, vol. 18, no. 4, pp. 235-247.

La Ferrara, E 2002, 'Self-help Groups and Income Generation in the Informal Settlements of Nairobi, Journal of African Economies, vol. 11, no. 1, pp. 61-89.

Mason, SO \& Fraser, CS 1998, 'Image sources for informal settlements management', Photogrammetric Record, vol. 16, no. 92, pp. 313-330.

MDLPL 2008, Metodologie de realizare a programelor de reabilitare a locuirii în zone afectate de degradare fizică şi excluziune socială, Ministerul Dezvoltării Regionale, Lucrărilor Publice și Locuințelor.

Mionel, V 2013,'Tipologia segregării geografice în mediul urban', Geographia Napocensis, Anul VII, No. 1, pp. 87-99.

Moser, C \& Peake, L 1987, Women, human settlements, and housing, Tavistock Publications, New York, p. 37.

Mutunayagam, NB 1974, Towards Principles for the Control of Squatter Settlements in Bangkok, Thailand, Community and Regional Planning Program: Faculty Scholarly and Creative Activity, Paper 10.

Nae, M 2007,'La taille des logements, densité et attachement résidentiels - facteurs limitatifs de l'habitat urbain bucarestois à l'impact visible sur la qualité de vie', HUMAN GEOGRAPHIES - Journal of Studies and Research in Human Geography, vol. 1, issue 1, pp. 117-124.

Parlamentul României 1995, Legea nr. 112 din 1995, privind reglementarea situaţiei juridice a unor immobile cu destinaţia de locuinţe, trecute în proprietatea statului. Legea caselor naţionalizate, Monitorul Oficial, Partea I, no. 279, november 29th, 1995 .

Parlamentul României 1998, Legea nr. 213 din 1998 privind proprietatea publică şi regimul juridic al acesteia, Monitorul Oficial, no. 448, november 24th, 1998.

Payne, G \& Majale, M 2004, The Urban Housing Manual: Making Regulatory Frameworks Work for the Poor, London, Earthscan.

Payne, GK 1977, Urban Housing in the Third World, Leonard Hill, London.

Peattie, L \& Aldrete-Hass, JA 1981, “"Marginal” Settlements in Developing Countries: Research, Advocacy of Policy, and Evolution of Programs', Annual Review of Sociology, vol. 7, pp. 157-175.

Plöger, J 2012,' Gated barriadas: Responses to urban insecurity in marginal settlements in Lima, Peru', Singapore Journal of Tropical Geography, vol. 33, pp. 212-225.

Pojani, D 2011,'Urban and suburban retail development in Albania's capital after socialism', Land Use Policy, vol. 28, issue 4, pp. $836-845$, ISSN 0264-8377,

Rodwin, L \& Sanyal, B 1987,'Shelter, settlement, and development: An overview', in L Rodwin (ed), Shelter, Settlement $\mathcal{E}$ Development, Allen and Unwin, Boston, pp. 39-47. 
Sabic, D, Knezevic, A, Vujadinovic, S, Golic, R, Milincic, M \& Joksimovic, M 2013, Elgrade Slums - Life Or Survival On The Margins Of Serbian Society?, Trames: A Journal of the Humanities and Social Sciences, vol. 17, no. 1, pp. 55-86.

Selwood, J \& Jones, R 2010,'Western Australian battlers and coastal squatter settlements: heritage from below versus regulation from above', Prairie Perspectives: Geographical Essays, vol. 13, pp. 78-85.

Smith, J 2009, Encyclopaedia Britannica, 8th ed., Encyclopaedia Britannica, Chicago, viewed on February 16, 2013, http://www.britannica.com/articles/id=2533.

Solaun, M, Flinn, WL \& Kronus, S 1974, 'Renovation of a Squatter Settlements in Colombia, Land Economics, vol. 5o, no. 2, pp. 152-162.

Srivinas, H 2005, Urban Squatters and Slums, www.gdrc.org/uem.

Suditu, B 2012,'Urban sprawl - the legal context and territorial practices in Romania', Human Geographies - Journal of Studies and Research in Human Geography, vol. 4, issue 2, pp. 74-77.

Tsenkova, S 2010, 'The Phenomenon of Informal Settlements in Post-Socialist Cities: Factors and Patterns of Diversity', Urban Challenge, vol. 21, no. 2, pp. 73-84.

Turner, J 1969, 'Uncontrolled Urban Settlement: Problems and Policies', in G Breese (ed), The City in Newly Developing Countries: Readings on Urbanism and Urbanization, Printice Hall, pp. 507-534.

United Nation 1996, Indicators of sustainable development. Framework and methodologies, United Nations, New York.

UNECE 2009, SELF MADE CITIES. In search of sustainable solutions for informal settlements in the United Nations Economic Commision for Europe Region, Geneve.

UN-HABITAT 1996, Urban management and land. Regularization and integration of irregular settlements: lessons from experience, Working paper no. 6, Nairobi, Kenya, http://ww2.unhabitat.org/programmes/ump/documents/ wp6.pdf

United Nations Economic and Social Commision for Asia and the Pacific 2003, Second Meeting of the Kitakyushu Initiative Network, 15-17 October 2003, Weitai, China.
United Nations Human Settlements Programme (UNHABITAT) 2003, Global Report on Human Settlements 2003, The Challenge of Slums, Earthscan, London.

United Nations Human Settlements Programme (UNHABITAT) 2010, Informal Urban Development in Europe Experiences from Albania and Greece, http://www.fig.net/pub/others/unhabitat_informal_urban_dev.pdf

Vienna Declaration 2004, Vienna Declaration on Informal Settlements in South Eastern Europe', Ministerial Conference on informal settlements in South Eastern Europe, Vienna, 28 September - o1 October 2004, viewed on October $25^{\text {th }}, 2007$,

http://www.stabilitypact.org/humi/o410o1conference.html.

Vuksanovic-Macura, Z 2012,'The mapping and enumeration of informal Roma settlements in Serbia', Environment and Urbanization, vol. 24, pp. 685-705.

Ward, PM 2001,'The Rehabilitation of Consolidated Irregular Settlements in Latin American Cities: Towards a Third Generation of Public Policy Housing Analysis and Development', Coping with Informality and Illegality in Human Settlements in Developing Countries, ESF Workshop, 2326 May,

http://www.ucl.ac.uk/dpu-projects/ drivers_urb_change/ urb_infrastructure/pdf_shelter_settlements/ESF_NAERU S_Ward_Rehabilitation_Settlements_Latin_American.pdf. Willis, KD 2009, Squatter settlements, Royal Holloway, University of London, Egham, pp. 403-408, http://digirep.rhul.ac.uk/file/a14bc3f3-oc7d-96a7-2207bfbaf259103a/3/Squatter_settlements.pdf.

Zetter, R \& De Souza, FAM 200o,'Understanding Processes of Informal Housing: Appropriate Methodological Tools for a Sensitive Research Area', International Planning Studies, vol. 5, issue 2.

Zhang, L, Zhao, SXB \& Tian, JP 2003, 'Self-help in housing and chengzhongcun in China's urbanization', International Journal of Urban and Regional Research, vol. 27, no. 4, pp. 912-937. 